\title{
Models for the Estimation of the Physical Quality of a Yellow Red Latosol (Oxisol) Under Pasture
}

\author{
Adriana Aparecida Ribon* and João Tavares Filho \\ Departamento de Agronomia;Universidade Estadual de Londrina-UEL; tavares@ uel.br; C. P. 6001; 86051-990; \\ Londrina - PR - Brazil
}

\begin{abstract}
Models were developed considering the physical parameters penetration resistance (RP), bulk density (Ds), gravimetric moisture (U), clay content (Ag), sand content (Ar) and organic matter (MO) collected from a Yellow Red Latosol (Oxissol) medium texture under pasture from Rondonópolis county district, Mato Grosso State. Sampling was carried out in 34 fully randomized points in a 1 ha area to the depth of $0-20 \mathrm{~cm}$. The models were created using the Statistical Analysis System program (SAS) through which linear multiple regressions and correlations were made. Using the determination coefficient the following model was selected: RP=$12.134+0.004 M O+7.6187 \mathrm{Ds}+0.131 \mathrm{AG}\left(R^{2}=0.78\right)$. The evaluation of the organic matter and the soil clay content were important tools to evaluate the physical quality of the soils, along with other physical soil properties that indicate soil compaction.
\end{abstract}

Key words: Modeling, penetration resistance, organic matter, texture

\section{INTRODUCTION}

In soils under pasture, the excessive compaction due to the trampling of the cattle is the major cause of its degradation. This compaction may be associated to the high pressure exerted by the feet of the animals and may be determined by the bulk density and penetration resistance, among other variables (Imhoff et al, 2000). Soil resistance to penetration is one of the physical properties that express the degree of compaction, and consequently, how easy the roots will penetrate the soil. Among the parameters that are important for the quantification of penetration resistance are bulk density and moisture; bulk density presents a direct relation with the resistance (Beltrame et al., 1981; Castro, 1995; Borges et al., 1999), and the water content influences negatively on the resistance (Beltrame et al., 1981; Correchel et al., 1997; Tormena et al, 1998). These relations have been studied in the literature through the establishment of regression models (Carter, 1990; Smith et al., 1997), and seek to model compaction through properties that indicate the physical quality of the soil. However, the established models or functions were developed for temperate regions, as the one developed by Carter (1990).

It is known that the process of soil compaction is influenced by the texture (Larson et al., 1980), because soils with different textural classes present distinct behavior in their physical properties when submitted to compaction. Another important factor that should be considered in the compaction process is the organic matter content (Assouline et al., 1997). Thus, penetration resistance, along with the bulk density and the

Author for correspondence 
moisture, is considered important as an indicator of the degree of compaction of cultivated soils. However, studies that relate these properties and consider the contribution of texture and organic matter in these models are scarce for tropical soils. The purpose of this study was to develop a model for the evaluation of the physical quality of a Yellow Red Latosol (Oxisol) medium texture under pasture considering the physical parameters penetration resistance, bulk density and moisture, along with the evaluation of the contribution of texture, represented by the content of clay and sand and the evaluation of the participation of the organic matter content.

\section{MATERIALS AND METHODS}

The experiment was carried out in a distroferric Yellow Red Latosol (Oxisol) medium texture (EMBRAPA, 1999), under pasture during the month of April 2000, in a one hectar in Rondópolis, Mato Grosso State, with its area defined by the coordinates: $15^{\circ} 57^{\prime} 47^{\prime \prime}$ to $17^{\circ} 18^{\prime} 00^{\prime \prime}$ - latitude south and $53^{\circ} 52^{\prime} 00^{\prime \prime}$ to $55^{\circ} 01^{\prime} 45^{\prime \prime}$ longitude west of Greenwich, with an altitude of $320 \mathrm{~m}$, with rainy (summer/autumn) and dry (winter/spring) climate. The area presents a pasture composed of Brachiaria decumbens and B.humidicola with a present occupation rate of 2.5 animals/ha. The pasture was implanted approximately 20 years ago when the area was tilled to implant the present pasture species. Presently, signs of surface erosion and the invasion of weed species are noticed. The penetration resistance was assessed using an IAA/PLANALSUCAR model impact penetrometer, as described by Stolf et al., (1983), totaling 34 repetitions. Stolf (1991) transformed the data obtained in impacts/cm of soil in dynamic resistance (MPa) using the formula proposed. At the moment of the determination of the penetration resistance, samples were taken for the determination of gravimetric moisture, granulometric composition, organic matter content, and the bulk density (EMBRAPA, 1997). The bulk density was determined by the volumetric ring method $\left(98 \mathrm{~cm}^{3}\right)$ in undeformed samples at the depth of $0.20 \mathrm{~m}$. For developing the models, an analysis was carried out with five independent variables represented by clay content $\left(\mathrm{X}_{1}\right)$, bulk density $\left(\mathrm{X}_{2}\right)$, sand $\left(\mathrm{X}_{3}\right)$ and organic matter $\left(\mathrm{X}_{4}\right)$ and one dependent variable characterized by the penetration resistance (Y). Normal distribution tests were applied for the selection of the variables to participate in the model, excluding those that didn't show a normal distribution of values. Afterwards, simple correlation analysis were carried out between the variables and multiple regression analysis using STEPWISE through the PROC REG procedure of the SAS System (1991) to model the effect of the properties in these conditions. The degree of significance for the $F$ value of the variable was $15 \%$ of probability for the inclusion and exclusion of variables in the model, according to Dias et al. (1999).

\section{RESULTS AND DISCUSSION}

The results of the variables selected for the obtention of a model that best estimated the physical quality of the Yellow Red Latosol under pasture are in Table 1, where a high variance coefficient could be observed for the soil resistance to penetration and clay content, due to the high amplitude in values for these two physical attributes. This variation could be explained by the influence of the management system because, according to Imhoff et al., (2001), in intensive pasture systems the probability of compactation by animals at the exact same place increased, causing a higher variation in the obtained results. The same happened to the bulk density because, in spite of the variation coeficient not being high, the difference between minimum and maximum values found indicated compactation in certain areas, probably because of the trampling of the cattle. The high variation in clay content was probably caused by loss of clay in the surface layer caused by surface erosion due to trampling by animals. 
Table 1 - Analytical Results for the variables participating in the model

\begin{tabular}{l|c|c|c|c|c}
\hline \multicolumn{1}{c|}{ Variables } & Average & $\begin{array}{c}\text { Standard } \\
\text { Deviation }\end{array}$ & CV(\%) & Minimum & Maximum \\
\hline Resistance $(\mathrm{MPa})$ & 2.27 & 1.23 & 54.13 & 0.88 & 6.29 \\
Bulk Density $\left(\mathrm{Mg} \mathrm{cm}^{-3}\right)$ & 1.58 & 0.10 & 6.34 & 1.35 & 1.78 \\
Gravimetric Moisture $\left(\mathrm{kg} \mathrm{kg}^{-1}\right)$ & 0.25 & 0.025 & 9.17 & 0.21 & 0.29 \\
Clay $\left(\mathrm{g} \mathrm{kg}^{-1}\right)$ & 148.58 & 52.67 & 34.35 & 87.0 & 267.2 \\
Sand $\left(\mathrm{g} \mathrm{kg}^{-1}\right)$ & 809.24 & 67.31 & 8.31 & 656.6 & 898.9 \\
Organic Matter $\left(\mathrm{g} \mathrm{dm}^{-3}\right)$ & 12.73 & 2.89 & 57.29 & 7.86 & 19.01 \\
\hline
\end{tabular}

After the analysis of these variables for the existence of a normal distribution for the exclusion of those that did not present this distribution it was inferred that only the gravimetric moisture had to be excluded. It is of common knowledge, however, that soil moisture is one of the important parameters for the quantification of penetration resistance and several studies have shown that the water content influences negatively the resistance (Beltrame et al., 1981; Correchel et al., 1997; Tormena et al., 1998). However in this experiment, probably this relation was not found due to the small amplitude of moisture that was found (Table 1). Hence, a more detailed study becomes important to explain the relation between penetration resistance and soil moisture, because in certain ranges of moisture, as in this case, moisture itself does not explain the variation in the values of penetration resistance. Ribon (2000), working with a small range of variation of gravimetric moisture as the one obtained in this experiment, using covariance analysis for the correction of averages of penetration resistance through gravimetric moisture, obtained corrected values for the averages close to the non-corrected averages, showing little influence of moisture on the obtained penetrometry data. The models obtained for the variables with normal distribution were selected by the determination coefficient $\left(\mathrm{R}^{2}\right)$, which measured the proportion of the sum of the squares of the dependent variable $(\mathrm{Y})$, explained by the regression model (Draper and Smith, 1981). In the Stepwise analysis, the first model proposed for the estimation of the mechanical resistance of the soil (Y) included only the variable bulk density with $\mathrm{R}^{2}=0.6569$, being the estimated model represented as seen on Table 2 .

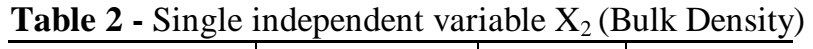

\begin{tabular}{c|c|c|c}
\hline Variables & $\begin{array}{c}\text { Parameter } \\
\text { Estimation }\end{array}$ & $\mathbf{F}$ & Prob>F \\
\hline Intercept & -13.5518 & 44.47 & 0.0001 \\
$\mathrm{X}_{2}\left(\mathrm{Mg} \mathrm{m}^{-3}\right)$ & 9.9600 & 61.29 & 0.0001 \\
\hline
\end{tabular}

As per the proposed model, there was a direct relation between penetration resistance and bulk density, with the bulk density explaining around $66 \%$ of this relation. This relation between the resistance to penetration and density has been discussed for models or functions (Beltrame et al., 1981; Castro, 1995; Borges et al., 1999). According to Arshad et al. (1996), penetration resistance values considered high for the restriction for root development were found in the range from 2 to $4 \mathrm{MPa}$.

Adopting these values for these conditions a critical density for the development of roots of Brachiaria decumbens and Brachiaria humidicola could be stated in the range of 1.56 to $1.76 \mathrm{~kg} \mathrm{dm}^{-3}$ (Fig. 1).

Imhoff et al. (2001), using the Least Limiting Water Range concept found values of bulk density critical to the development of sugar cane roots of $1.56 \mathrm{Mg} \mathrm{m}^{-3}$ for a penetration resistance of 1.0 $\mathrm{MPa}$ and of $1.78 \mathrm{Mg} \mathrm{dm}^{-3}$ for a penetrationl resistance of 3.0 MPa in a Yellow Red Podzolic.

The second variable included in the model was organic matter, which contributed for a significant rise in the determination coefficient, obtaining a value of 0.75 , which helped us to propose the model seen on Table 3 .

The simple linear relations obtained between this property and penetration resistance and bulk density (Fig. 2) could explain this result. Fig. 2 shows a low correlation between organic matter and the physical properties penetration resistance and bulk density, indicating a non-beneficial effect of the organic matter over soil. 


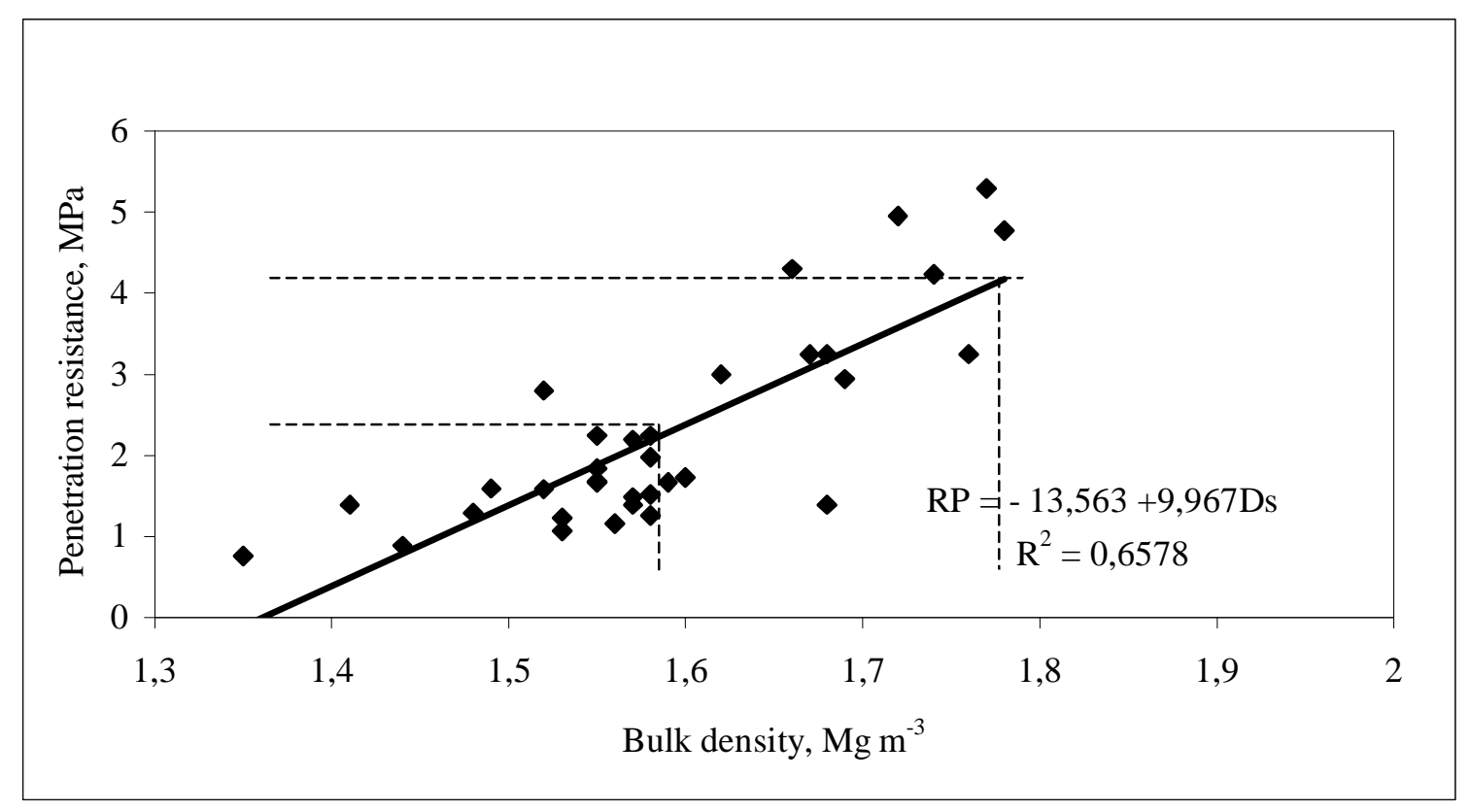

Figure 1 - Correlation between penetration resistance and bulk density for the Yellow Red Latosol under pasture.

Table 3 - Bulk Density $\left(\mathrm{X}_{2}\right)$ and organic matter $\left(\mathrm{X}_{4}\right)$ as independent variables

\begin{tabular}{l|c|c|c}
\hline Variables & $\begin{array}{c}\text { Parameter } \\
\text { Estimation }\end{array}$ & F & Prob>F \\
\hline Intercept & -11.2388 & 35.68 & 0.0001 \\
$\mathrm{X}_{2}\left(\mathrm{Mg} \mathrm{cm}^{-3}\right)$ & 7.1999 & 27.71 & 0.0001 \\
$\mathrm{X}_{4}\left(\mathrm{~g} \mathrm{dm}^{-3}\right)$ & 0.1626 & 11.62 & 0.0018 \\
\hline
\end{tabular}

These data were in accordance to those Carter (1990) who, using Stepwise analysis to evaluate the relations between the mechanical properties shear strenght, penetration resistance, bulk density and macroporosity in soils of temperate regions, found the best model having a positive relation between the content of organic carbon and the dependent variable shear strenght, expressed by: shear strenght $=-13.0+29.89$ bulk density -0.37 macroporosity -0.29 fine sand +0.67 clay +1.52 organic carbon.

Probably, the direct relation obtained by the organic matter and penetration resistance could be explained by the fact that organic matter has a cementing property on the particles facilitating the formation of block structures, which results in an increase of the penetration resistance of the soil. Hence, through the results obtained in this experiment, the necessity of more detailed studies over the effects of organic matter on the compaction of tropical soils becomes perceivable and we could show that this property should be taken into consideration in studies of models for the evaluation of the physical quality of the soils, because according to Ekwue and Stone (1995), the influence of organic matter on agricultural soil compaction depended not only on its percentage, but also on the type of the organic matter. However, for this study, more detailed studies would be necessary to attribute this fact to the type of organic matter present on the soil. The last variable selected for inclusion in the model was the soil clay content, presenting the model shown on Table 4.

Table 4 - Bulk density $\left(X_{2}\right)$, organic matter $\left(X_{4}\right)$ and Clay Content $\left(\mathrm{X}_{1}\right)$ as independent variables

\begin{tabular}{l|c|c|c}
\hline Variables & $\begin{array}{c}\text { Parameter } \\
\text { Estimation }\end{array}$ & F & Prob>F \\
\hline Intercept & -12.1348 & 42.91 & 0.0001 \\
$\mathrm{X}_{2}(\mathrm{Mg} \mathrm{cm}$ & 0.0043 & 3.98 & 0.0553 \\
$\left.{ }^{3}\right)$ & & & \\
$\mathrm{X}_{4}\left(\mathrm{~g} \mathrm{dm}^{-3}\right)$ & 7.6187 & 33.15 & 0.0001 \\
$\mathrm{X}_{1}\left(\mathrm{~g} \mathrm{~kg}^{-1}\right)$ & 0.1311 & 7.38 & 0.0109 \\
\hline
\end{tabular}



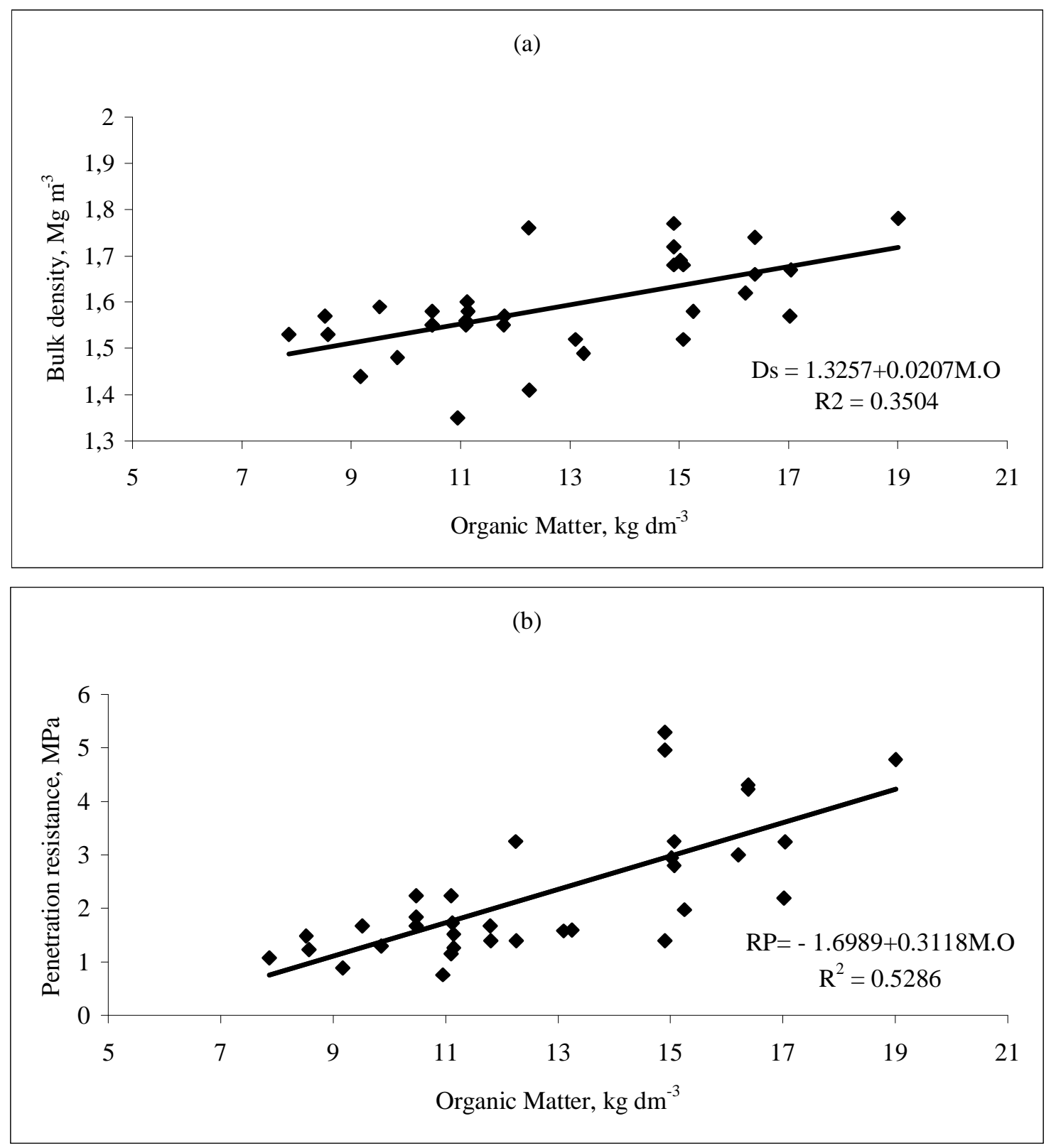

Figure 2 - Correlations between organic matter and bulk density (a) and soil resistance (b) for the Yellow Red Latosol under pasture.

Hence, for this soil, clay represented the textural class that most contributed to explain the nature of the relations among the other variables participating in the model, explaining around $78 \%$ of these relations. Carter (1990) also used the Stepwise model to establish regression equations on the study of relations between the mechanical properties shear strenhgt, penetration resistance, bulk density and macroporosity in soils of temperate regions and obtained a determination coeficient of 0.78 with the inclusion of fine sand, clay and organic carbon.

Mapfuno and Chanasky (1998) reported that the different textural classes of the soil modified the relations between penetration resistance and bulk density. These authors observed that for clayey soils, considering a critical resistance of $2.0 \mathrm{MPa}$ as impeding to the crop root system, the critical density was of $1.63 \mathrm{Mg} \mathrm{m}^{-3}$ and for sandy soils the critical density ranged from 1.54 to $2.07 \mathrm{Mg} \mathrm{m}^{-3}$ 
in function of moisture levels. In the model, besides the relation of clay to physical properties penetration resistance and bulk density, a straight dependency of clay content with the organic matter of the soils should be considered. Pinotti (1997) also reported through the Stepwise procedure models for the characterization of physical, chemical and mineralogical attributes a fine relation between the texture represented by the clay content and the organic matter in some soils of São Paulo State. The sand content was excluded from the model probably because of the level of $15 \%$ of significance for the inclusion of variables. Dias et al (1999), also in a field study, to relate sugarcane yield through Stepwise, also used the Stepwise model considering a $15 \%$ default adequate for the input and output of the variables of the model. The simplicity on obtaining the selected parameters that made up the best model selected by the higher value of $\mathrm{R}^{2}$ made the application of this model viable, because it included the physical properties bulk density and penetration resistance which were obtained from quick and simple assessments in the field and also included organic matter and clay content, which were part of the routine analysis.

\section{CONCLUSIONS}

Under the conditions that this experiment was carried out we concluded that:

1. The model that best allowed the estimation of the physical quality of the Yellow-Red Latosol medium texture under pasture was the one that correlated penetration resistance (RP), bulk density (Ds), organic matter (MO) content and clay (AG) content: $\mathrm{RP}=-$ $12.134+0.004 \mathrm{MO}+7.6187 \mathrm{Ds}+0.131 \mathrm{AG}$.

2. The evaluation of the organic matter and clay content of the soils were important tools, along with the other physical properties that indicated soil compaction on the assessment of physical quality.

3. The moisture content didn't explain the variation on the values of penetration resistance obtained for the Yellow Red Latosol under pasture, making a more detailed study necessary to explain the relation between resistance and soil moisture.

\section{RESUMO}

Modelos ou funções que envolvem variáveis indicadoras da compactação do solo (resistência do solo à penetração, densidade do solo e umidade) são importantes ferramentas na avaliação da qualidade física dos solos. Porém, são escassos os estudos que consideram também a contribuição da composição granulométrica e matéria orgânica nestes modelos em solos tropicais. Neste sentido, foram elaborados modelos considerando os parâmetros físicos resistência mecânica (RP), densidade do solo (Ds), umidade gravimétrica (U), conteúdo de argila $(\mathrm{Ag})$, conteúdo de areia (Ar) e matéria orgânica (MO) coletados em um Latossolo Vermelho-Amarelo textura média sob pastagem do município de Rondonópolis - MT. Numa área de 1ha foram realizados 34 pontos de amostragem inteiramente casualizados na profundidade de $0-20 \mathrm{~cm}$. Os modelos foram obtidos por meio do Programa Statistical Analysis System (SAS) onde foram realizadas correlações e regressões lineares múltiplas por Stepwise, considerando como variável dependente a resistência do solo à penetração de raízes. Através do coeficiente de determinação foi selecionado o seguinte modelo: $\mathrm{RP}=-12,134+0,004 \mathrm{MO}+7,6187 \mathrm{Ds}+0,131 \mathrm{AG}$

$\left(\mathrm{R}^{2}=0,78\right)$. A matéria orgânica e a argila dos solos são importantes ferramentas, juntamente com as outras propriedades físicas indicadoras da compactação na avaliação da qualidade física dos solos.

\section{REFERENCES}

Arshad, M. A.; Lowery, B. and Grossman, B. (1996.), Physical tests for monitoring soil quality. In: Doran, J. W. and Jones, A. J. (eds.). Methods for assessing soil quality. Madison, Soil Science Society of America, 49, 123-142.

Assouline, S.; Tavares-Filho, J. and Tessier, D. (1997), Effect if compaction on soil physical properties: experimental results and modeling. Soil Science Society American Journal, 61, 391-398.

Beltrame, L. F. S.; Gondim, L. A. P. and Taylor, J. C.(1981). Estrutura e compactação na permeabilidade de solos do Rio Grande do Sul. Rev Bras. Ci. Solo., 5, 145-149. 
Borges, A. L.; Kiehl, J. and Souza, L. S. (1999), Alteração de propriedades físicas e atividade microbiana de um Latossolo Amarelo álico após cultivo com fruteiras perenes e mandioca, Rev. Bras. Ci. Solo., 23, 1019-1025.

Castro, O. M. (1995), Comportamento físico e químico de um latossolo Roxo em função do seu preparo na cultura do milho (Zea mays 1.), Piracicaba. (Tese de Doutorado em Solos e Nutrição de Plantas) - Escola Superior de Agricultura Luiz de Queiroz Universidade de São Paulo. 174 pp.

Carter, M. R. (1990), Relations of strength properties to bulk density and macroporosity in cultivated loamy sand to loam soils. Soil Till. Res., 15, 257-268.

Correchel, V.; Silva, A. P. and Tormena, C. A.(1997), Resistência de um Latossolo Roxo em dois sistemas de preparo do solo. In: Congresso Brasileiro de Ciência do Solo, 26. Rio de Janeiro. pp. 20.

Dias, F. L. F.; Mazza, J. A.; Matsuoka, S.; Perecin, D. and Maule, R. F.(1999), Relação entre produtividade, clima, solos e variedades de cana-de-açúcar na região noroeste do Estado de São Paulo. Rev. Bras. Ci. Solo, 23, 627-34.

Draper, N. R. and Smith, H. (1981), Applied regression Analysis. New York : John.

Ekwue, E. I. and Stone, R. J. (1995), Organic matter effects on the strenght properties of compact agricultural soils. Transections of the ASAE, 38, 357-365.

EMBRAPA (1997), Manual de Métodos de Análise de Solo. 2. ed. Rio de Janeiro : SNLCS. 212 pp.

EMBRAPA. Centro Nacional de Pesquisa de Solos (Rio de Janeiro/RJ). Sistema Brasileiro de Classificação de Solos (1999), Serviço de produção de informação. Brasília. 412 pp.

Imhoff, S.; Pires da Silva, A. and Tormena, C. A. (2000), Aplicações da curva de resistência no controle da qualidade física de um solo sob pastagem. Pesq. Agropec. Bras., 35, 1493-1500.

Imhoff, S.; Pires da Silva, A.; Dias Júnior, M. S. and Tormena, C. A. (2001), Quantificação de pressões críticas para o crescimento das plantas. Rev Bras. Ci. Solo., 25, 11-18.
Larson, W. E.; Gupta, S. C. and Useche, R. A. (1980), Compression of agricultural soils from eight soil orders. Soil Science Society of American Journal., 44, 450-457.

Mapfuno, E. and Chanasyk, D. S. (1998), Guidelines for safe trafficking and cultivation, and resistancedensity-moisture relations of three disturbed soils for Alberda. Soil Till Res., 46, 383-397.

Pinotti, A. A. (1997), Caracterização e correlação de atributos de alguns solos do Estado de São Paulo. Trabalho de graduação apresentado à Universidade Estadual Paulista - UNESP. 93 pp.

Ribon, A. A. (2000), Propriedades físicas de Latossolo e Podzólico cultivados com seringueira (Hevea brasiliensis) submetidos a práticas de manejos no Planalto Ocidental Paulista, Jaboticabal. (Dissertação de Mestrado em Ciência do Solo) Faculdade de Ciências Agrárias e Veterinárias Universidade Estadual Paulista. 130 pp.

SAS Institute (1991), SAS/STAT procedure guide for personal computers. 5. ed. SAS Inst., Cary, N. C.

Smith, C. W.; Johnston, M. A. and Lorentz, S. (1997), The effect of soil compaction and soil physical properties on the mechanical resistance of south African forest soils. Geoderma., 78, 93-111.

Stolf, R.; Fernandes, J. and Furlani Neto, V. L. (1983), Penetrômetro de impacto IAA/PLANALSUCARSTOLF: recomendação para seu uso. STAB, 3, 18-23.

Stolf, R. (1991), Teoria e teste experimental de fórmulas de transformação dos dados de penetrômetro de impacto em resistência do solo. Rev. Bras. Ci. Solo, 15, 249-252.

Tormena, C. A.; Silva, A. P. and Libardi, P. L. (1998), Caracterização e avaliação do intervalo hídrico ótimo de um Latossolo Roxo. Rev Bras. Ci. Solo, 22, 573-581.

Received: April 19, 2002; Revised: October 04, 2002 ; Accepted: July 28, 2003. 